\title{
The Emerging Retail Market in Myanmar - An Institutional Perspective of Foreign Retailers' Market Entry Decisions
}

\author{
Sina Hardaker ${ }^{1}$ \\ ${ }^{1}$ Julius-Maximilians-University, Würzburg, Germany \\ Correspondence: Sina Hardaker, Department of Economic Geography, Julius-Maximilians-University, Bavaria, \\ 97074 Würzburg, Germany.
}

Received: October 30, 2017

Accepted: November 16, 2017 Online Published: November 23, 2017

doi:10.5539/ibr.v11n1p19

URL: https://doi.org/10.5539/ibr.v11n1p19

\begin{abstract}
In contrast to most of its Southeast Asian neighbors, Myanmar still lacks a vibrant retail landscape. Yet, given the political and economic opening-up of the country and the abolition of many sanctions since 2013, commercial interest in Myanmar is growing rapidly. While political and economic reforms sweep across the country, retailers are now eyeing-up the formerly reclusive nation for opportunities. Still, the question remains as to how optimistic the outlook of the Myanmar retailing industry really is? This paper explores and analyses the developments of Myanmar's retail sector to date. Within the decision making process, companies operate within an external and an internal environment that consist of political, cognitive and sociological elements. A company's behavior and decision making processes are affected by both environments. This study applies institutional theory as a complementary framework in order to evaluate international retailers' foreign market entry choices with special regard to Myanmar and evaluates the main factors influencing decisions for, or against market entry. It concludes by proposing institutional theory as complementary to, and not substitutive of, existing theories such as Dunning's eclectic theory or transaction cost analysis.
\end{abstract}

Keywords: Myanmar, retail, economic development, institutional theory, market entry decision, Southeast Asia

\section{Introduction}

Although retailers, particularly food retailers, have started late with their international expansion, they are increasingly recognizing developing markets as a means of strategic growth and are responding accordingly. Within the decision-making process they are influenced by internal and external framework conditions, which in turn consist of regulatory, normative and cognitive elements. The present study applies institutional theory as a complementary framework to assess the selection criteria of international retailers with regard to the Myanmar market. The author concentrates on the investigation of external framework conditions and their impact on international food retailers. Given the political and economic opening-up of the country and the abolition of many sanctions since 2013, interest in Myanmar is considerable. With about 51 million inhabitants Myanmar is not only embedded between the global economic powers of China and India, but also in the middle of ASEAN 's fastest growing economic region and is increasingly opening the gates for visitors and investors from all over the world. While political and economic reforms are sweeping through Myanmar, retailers are also turning their attention to the formerly isolated nation. International heavyweights such as Burger King, Coca-Cola and others are entering a seemingly promising market. But how optimistic are the prospects for retailing in Myanmar? The article has two objectives: (1) To use the institutional theory as a framework to explain the possibilities for international retailers to enter Myanmar; (2) To assess the reasons why retailers have not (yet) entered the Myanmar market. The question of the influence factors on the decision-making of the international expansion of the retailers in Myanmar is investigated by means of an institutional-theoretical analysis of the external company environment. Thereby, the present study builds upon earlier research by Huang and Sternquist (2007).

\section{Internationalization of Retail - Developing Countries as Growth Engines}

The internationalization of retail has intensified enormously over the last 30 years and has led to a considerable volume of academic research. The international retail trade, as defined by Alexander (1997: 36), describes "the management of retail operations in markets which are different from each other in their regulation, economic development, social conditions, cultural environment, and retail structure". Burt (1991: 513) notes that retail internationalization is not a linear, uninterrupted development, but a complex process. Companies generally 
prefer markets with high attractiveness, low risk and high probability of a competitive advantage. The key issues raised by companies concerned with regard to international expansion include not only the point of entry (market entry into a particular country), but the entry mode (how should the market be entered) and the date of entry (when should the market be entered). While Zentes et al. (2011) distinguish between four basic types of international retailing (1) domestic market orientation, (2) global orientation, (3) multinational orientation, and (4) globalization, Sternquist (1997), in his study of the expansion of US retailers, chooses two types of internationalization strategies. Firstly, the global expansion model, under which no significant changes are made. Secondly, the multinational expansion model in the context of which retailing concepts are correspondingly modified and thus adapted to the cultural differences of the respective country. Traditionally, the different forces that move a company to expand are classified as push or pull factors. These factors include, among others, cultural proximity, market size and geographic distance, but also the saturation of the home market (Sternquist 1997). Salmon and Tordjman's (1989) classification includes a third retail strategy. The investment strategy describes the purchase of an existing retailer in the non-domestic market in the case of isolated development of the various markets.

While the internationalization of the retail sector is not a new phenomenon (Coe \& Lee 2006), the breadth and speed of expansion into new markets has been unprecedented over the past ten years. The internationalization of trade has intensified and this trend will undoubtedly continue (Wang \& Zhang, 2005; Dawson \& Mukoyama, 2014a). In view of the importance of the sector and the number of companies involved, the internationalization process in food retailing has nevertheless occurred much later than in the processing industry (Vida et al., 2000; Huang \& Sternquist, 2007; Zhen, 2007). This is confirmed by Corstjens and Lal's assertion that " $[s]$ ome industries clearly cannot travel across borders as well as others," and the fact that food retailing is dominated by local actors in most countries. However, food retailers are often exposed to very limited growth prospects in their home markets (Gielens \& Dekimpe, 2002; Dawson \& Mukoyama, 2014b). Traill (2006), who examines the rapid global rise in supermarkets, indicates significant growth in countries opening their market and increasing their gross domestic product, both factors which apply to the Myanmar market. Emerging markets are playing an increasingly important role in the internationalization of retail. The annual Global Retail Development Index (GRDI) of the consulting company A.T. Kearney makes this clear:

"A lot has changed since we published the first A.T. Kearney Global Retail Development Index ${ }^{\mathrm{TM}}\left(\right.$ GRDI) ${ }^{1} 15$ years ago, but one thing has been fairly constant: Retail in developing countries has seen excellent growth. While the developing world population has grown 21 percent to 6.2 billion, retail sales in those markets have increased more than 350 percent and now represent more than half of total global retail sales." (A.T.Kearney, 2016: 1)

As a result, the retail trade in emerging markets presents a frequently analyzed subject in research literature (eg. Coe \& Wrigley, 2007: 341; Reinartz et al., 2011: 53f; Tandon et al., 2011: 327; Swoboda et al., 2012). In his study, Coe (2004: 1571) emphasizes the geographic expansion of internationalization, pointing particularly to the growth regions in Latin America and Southeast Asia. There are a number of reasons for these spatial shifts. While some factors are linked to previous experiences in the internationalization process, others are directly linked to the emerging markets themselves (Reardon et al., 2007a: 401f .; Sakarya et al., 2007: 213; Senauer \& Reardon, 2011: 282), which is characterized by an increasing degree of economic liberalization, a rising urbanization rate, weaker competition and a new emerging middle class (Cavusgil et al., 2013: 2f.), factors which also apply to the Myanmar market.

The top 100 leading retailers in developed countries earn $36 \%$ of their revenues in emerging markets, although these markets represent only 17\% of the global gross domestic product (GDP) (Atsmon et al., 2012: 3), thus underlining the argument for large growth opportunities. Alexander and De Lira e Silva (2002: 300) call geopolitics, economics and conditions of competition as fundamental drivers of the changing geographical areas of interest of international expansion. In their study "The supermarket revolution of developing countries" Reardon et al. (2007a: 407f.) as well as Senauer and Reardon (2011: 276f.) differentiate four different diffusion waves. The first wave lasted from the beginning to the middle of the 1990s and started mainly in South America and East Asia, outside of China and Japan. The second wave (mid to late 1990s) occurred in Mexico, in many

\footnotetext{
${ }^{1}$ The GRDI classifies the top 30 developing countries for trade investment, based on several macroeconomic and retail - specific variables on a 0 to 100 point scale - the higher the rank the higher the urgency to enter the market. The countries are selected from 200 developing countries on the basis of criteria such as country risk, population and wealth. GRDI points are based on four variables: (1) land and business risks; (2) market actress; (3) market saturation and (4) time pressure (A.T. Kearney, 2016: 2).
} 
parts of Southeast Asia, southern and central Europe, and Central America, while the third wave (early 2000s) spread to many African countries as well as Central and South America, India, Russia and China. Beginning in the middle of 2000, the authors describe an emerging fourth wave in currently less industrialized countries such as Cambodia, Bolivia and sub-Saharan Africa. Several studies of retail internationalization exist for emerging markets such as Tunisia (Amine \& Tanfous, 2012), Turkey and Morocco (Codron et al., 2004; Appel, 2014), South Africa (D'Haese \& Van Huylenbroeck, 2005), Latin American countries such as Chile (Faiguenbaum et al., 2002; Reardon et al., 2007b), the four BRIC nations of Brazil (Alexander \& De Lira and Silva, 2002), Russia (Lorentz \& Hilmola, 2008), India (Reardon \& Gulati, 2008; Akther \& Equbal, 2012) and China (Cao \& Pederzoli, 2013; Hardaker, 2017), the East Asian region as a whole (Larke, 2006), as well as a variety of South Asian states such as Vietnam (Hagen, 2002; Maruyama \& Trung, 2007; Fliguié \& Moustier, 2009; Nguyen et al., 2013) and Malaysia (Hassan et al., 2013). As far as Myanmar's retail trade is concerned, no academic studies exist to current knowledge of the author.

According to A.T. Kearneys GRDI developing and emerging countries remain the main growth engine in the retail sector. The world's leading food retailers are therefore concentrating their expansion plans on the se growth markets. Walmart is pushing forward its development in China and Mexico, while Carrefour is accelerating the expansion of its stores in various markets such as Brazil and the Middle East, as well as opening shops in Qatar and Kenya. Tesco is planning to expand in India, and Metro is also working on the Russian market and continuing to focus on China (IGD, 2014).

The first three places of the GDRI 2016 are held by China, India and Malaysia. In particular, Asian markets demonstrate a high attractiveness for retailers and potential investors (A.T. Kearney 2016: 2). Even though Myanmar is not yet mentioned in the GRDI, the Myanmar market can currently be classified - according to the author - at the beginning of the introductory phase.

Nevertheless, the internationalization process of retailers is not always successful. On the contrary, food retailers often encounter great difficulties in realizing the potential when entering new markets. Very often, the retailer's market share is relatively small compared to the home market. In some cases, companies have to acknowledge their failures by leaving the market entirely. These market divestments have led to a sharp increase in academic literature discussing this phenomenon (Alexander \& Quinn, 2002; Burt et al., 2004; Palmer, 2004; Alexander et al., 2005). Nevertheless, the internationalization of retailers continues to grow. Although the Myanmar market is characterized by a very low degree of internationalization and a strong fragmentation, international retailers are increasingly showing their interest in entering the market. Consequently, the decision-making process of a retailer whether or not to enter the Myanmar market is an essential factor when analysing reasons for the current increasing internationalization of the retail landscape in Myanmar and its future. The country's environment needs to be analyzed in terms of regulatory, normative and cognitive elements to explain its impact on the behavior of a company.

\section{Theoretical Framework: Institutional Theory}

Earlier research often uses the eclectic theory of Dunning $(1977,2003)$ and the transaction cost analysis (Williamson 1979, 1981) as an explanatory approach of the internationalization of firms. Concerns about the explanatory boundaries of these theories were, inter alia, expressed by Huang and Sternquist (2007) who propose and apply the theory of institutions as a useful and complementary explanation for the decision-making process of firms abroad. King et al. (1994: 141) define an institution as "any standing social entity that exerts influence and regulation over other social entities". In their research, institutions are considered as the combination of government and social context, leading to the employment of two mature models, namely King et al.'s (1994) institutional framework and DiMaggio and Powell's (1983) institutional isomorphism. Since the 1970s, institutional theory continues to represent a prevailing and dynamic theoretical tradition (Lounsbury \& Beckman, 2015), emphasizing "the relationship between organizations and the environment" (Huang \& Sternquist, 2007: 614). Scott (1995: 33), offering a widely renowned definition of institutions, describes the latter as consisting "of cognitive, normative, and regulative structures and activities that provide stability and meaning to social behavior. Institutions are transported by various carriers - cultures, structures, and routines - and they operate at multiple levels of jurisdiction." Consequently, companies need not only capital, knowledge, material, etc., but also depend on the acceptance of the society in which they operate. This is especially crucial when companies are changing spatially and expanding. These changes, driven by globalization, influence the institutional context in a new and diverse way through differing markets and intercultural contexts. When deciding for a new country, it is essential for the company not only to adapt to the new market environment, but also to the institutional environment. Each of these elements (regulatory, normative, cognitive), as shown in Figure 1, form a basis for legitimacy - a condition that reflects the consistency with rules or laws, normative support, or cultural orientation (Scott, 1995). 


\begin{tabular}{|l|lll|}
\hline & Regulative & Normative & Cognitive \\
\hline Basis of compliance & Expedience & Social obligation & Taken for granted \\
Mechanism & Coercive & Normative & Mimetic \\
Logic & Instrumentality & Appropriateness & Orthodoxy \\
Indicators & Rules, laws, sanctions & Certification, & Prevalence, \\
& & accreditation & isomophism \\
Basis of legitimacy & Legally sanctioned & Morally governed & Culturally supported, \\
& & & conceptually correct \\
\hline
\end{tabular}

Figure 1. Three pillars of institution (own illustration based on Scott, 1995: 35)

Within the framework of the regulatory dimension, institutional theory emphasizes legal and political factors, which are often very specific, depending on the country. According to Scott (1995), the strongest influences that organizations face are legal regulations in their home country as well as in the foreign market. For the retail sector a wide range of laws and regulations are formulated which encourage or inhibit retailers to enter the market. Vida et al. (2000) refer, for example, to the laws on opening-times in Germany, which limits the opening hours of retailers. The regulatory element thus emphasizes the conformity of legal systems as the basis of legitimacy. Normative components introduce "a prescriptive, evaluative, and obligatory dimension into social life" (Scott, 1995: 37) and help to understand how "values and normative frameworks structure choice" (Scott, 1995: 38). In order to be successful, a company's practices have to comply with local value systems. Legitimacy is an important factor for the acquisition, survival and performance of resources, which can typically be summarized as 'effectiveness' according to Powell and DiMaggio (1991). While internalized commitments and moral convictions have priority, the normative mechanism aims at the organization's desire to behave adequately according to internalized behavior and other expectations (Scott, 1995).

Since the company's decisions also depend on social and cultural factors (Simon, 1959), the cultural distance between the home and foreign market strongly affects the decision-making process. Kogut and Singh (1988: 422) define cultural distance as "the degree of difference in cultural norms between countries." Cultural distance includes a variety of differences in the legal order of a country, administrative practices, consumer habits and working styles, then again increasing the integration costs of an international retailer (Hofstede, 1980). Two opposing theories attempt to explain attitude and behavior in different countries: On the one hand, the convergence theory assumes that industrializations exhibit the same behavior while they differ culturally. Conversely, the divergent theory asserts that individual attitudes change, although the economy and society of two countries tend to agree (Xu-Priour \& Cliquet, 2013). The normative element emphasizes the moral basis for the evaluation of the legitimacy accordingly, and the cognitive element emphasizes the cultural legitimacy, which results from the assumption of a common way of thinking. Representatives of cognitive theory (e.g., Powell \& DiMaggio, 1991) focus on conceptual concepts, mental models, and interpretations of common meanings that represent the influences from the perspective of the microenvironment. In contrast to the disadvantages of the macroenvironment (home and host market), the micro-environment presents challenges that arise from the company itself (Davis et al., 2000).

In the last three decades the theory of institutional theory has produced a significant literature volume (Aldrich \& Fiol, 1994; Suchman, 1995; Peng \& Heath, 1996; Dacin, 1997; Lawrence et al., 2001; Sherer \& Lee, 2002; Aten \& Howard-Grenville, 2012; Zilber, 2012). Powell and DiMaggio's (1991: 1) objection is still valid today: “it is often easier to gain agreement about what it is not than about what it is". The institutional environment influences the organizational behavior of a company, which is integrated into its own internal and external organization. While internal frameworks consist of the established standards, structures and decisions, the external institutional environment includes a number of other organizations, such as customers, suppliers, authorities and competitors (Meyer \& Rowan, 1977).

In response to Vida et al.'s (2000) call "for the inclusion of external environment factors into the development of a model of retail internationalization by introducing institutional theory as a potential theoretical framework", Huang und Sternquist (2007: 614) emphasize the differences between retailers and producers within the framework of international expansion. They stress the high cultural sensitivity of the retail sector, particularly the food industry. The internationalization of grocery retailers proves to be particularly difficult, as the customer has to be approached directly with a comprehensive offer consisting of the provision of goods and services on the spot (Turban \& Wolf, 2008). While fashion trends occur on a global scale, food retailers are facing a much more 
complex market, in which eating habits can be very different, even within a market. Food retailers have to a certain extent to become a substantial part of the community itself in which they wish to conduct business. Failure estimates can lead to undesirable consequences and even result in a market exit. Examples include Walmart in Germany (Senge, 2004; Christopherson, 2007) and South Korea (Halpete et al., 2008), Aldi in Greece (Handelsblatt, 2010), Walmart and Carrefour in Korea (Young-Sang, 2011) and Tesco's "Fresh \& Easy" in the USA (Euromonitor, 2013).

Huang and Sternquist (2007) note that studies to date mainly focus on the application of institutional theory to the domestic retail sector. They argue, however, that retailers are exposed to isomorphic pressure - both from their own internal environment as well as from the external environment of the respective country.

Institutional frameworks therefore influence business decisions. Each of the elements (regulatory, normative and cognitive) provides a basis for the legitimacy of the company's decision - a condition that reflects congruence with rules or laws, normative support, or cultural orientation. Companies are therefore trying to gain legitimacy by respecting the social system of their institutional environment. They achieve this through isomorphism, a compelling process that creates units when exposed to the same environmental conditions. Therefore, the institutional theory may prove useful in analyzing the market entry opportunities of retailers in the international arena. The conceptualisation of institutional theory therefore serves as the basis for the investigation of food retailing in Myanmar and is primarily used to examine the external environment of a retail company within the decision-making process.

\subsection{The Institutional Framework of Myanmar - Current Developments}

Akehurst and Alexander (1995: 6) confirm that the study of retail internationalization processes of is "the study of contextualized change over time." The analysis of the retail environment must therefore encompass a broader economic and social context. Au-Yeung (2003: 136) underlines the importance of "differences in economic, social, cultural, technological and political conditions (...)", since “(...) retail expertise is rooted in a specific set of underlying (...) conditions and level of infrastructure development."

Myanmar is gradually becoming an attractive food retail market. From 2012 to the end of 2014, Myanmar's retail trade grew by an estimated 7-15\% per year, in line with GDP growth of over 7\% over the same period last year (Oxford Business Group, 2016). From 2009 to 2013, all categories of consumer goods recorded a significant increase in sales. Packaged groceries augmented by $12 \%$, with the sale of canned food and baby food revealing the most significant increase ( 24 and $22 \%$ respectively). For 2014 to 2018 a growth of $15 \%$ is predicted for the consumer goods industry. Soft drinks experienced an average annual growth rate of $18 \%$ between 2009 and 2013, and growth rates of $23 \%$ are predicted for 2014 to 2018 (Euromonitor, 2014).

Generally, the economic potential of the country is enormous. McKinsey writes of a "key moment" (2013:1) in the history of Myanmar, while Germany Trade and Invest (2013) speaks of a "gigantic catching up, supported by continuous increases in employment and purchasing power". The modern retail sector in Myanmar is still in its infancy, while $90 \%$ of retail sales are still traded on traditional markets, so-called wet markets. $10 \%$ which are classified as 'modern', are mostly supermarkets, which are concentrated in the three main population centers of Myanmar: Yangon (the economic center with about 4 million inhabitants), Naypyidaw (go vernment seat, about 1 million inhabitants) and Mandalay second largest city with about 1.1 million inhabitants). The still small share of retail sales through modern formats is said to increase to $25 \%$ by 2020 (IGD, 2015).

In fact, Myanmar is rapidly developing a new retail structure that orientates itself on more developed Asian neighbors. Although traditional markets still dominate the sector and remain an integral part of the purchasing behavior of the people of Myanmar, over 50\% of people in Yangon visit a grocery store and 30\% a convenience store. The situation seems to change quickly: Modern retailers are moving in, and some are communicating aggressive expansion plans, even in Myanmar's second-tier cities (Euromonitor, 2014). In 2012, Coca-Cola reported its market reentry. After more than 60 years, Coca-Cola will be delivered again in Myanmar (The China Post, 2012). The Wall Street Journal (2013) reports an investment of around US \$ 1 billion by Coca-Cola and Unilever, which are the largest commitments made by Western multinational companies in Myanmar so far. In June 2015, KFC opened the first large US fast food chain (The Jakarta Post, 2015), with Burger Kind following in July 2016 (Planet Retail, 2016). The Krispy Kreme restaurant chain, founded in North Carolina, plans to open ten stores by 2020 (Retail in Asia, 2015a). As the first American clothing retailer, Gap Inc. has announced that it will produce clothing in two factories in Yangon (Retail in Asia, 2014). Other US companies include Chevrolet and Ford, as well as the beverage producer Pepsi, which already have a presence in Myanmar (The Jakarta Post, 2015).

The current market leader in the retail sector is City Mart Holding, which includes not only supermarkets (City Mart) and hyper markets (Ocean Supercenter), but also pharmacies (City Medicypharmacy), cafés (Seasons 
Bakery \& Café) and Shopping Malls (Cost Point, North Point). The vast majority of the sites are located in Yangon, surpassing the competitors Orange, Asia Light and Dagon (Germany Trade and Invest, 2013). It was not until the beginning of 2016 that City Mart Holding announced that it would receive a US \$ 25 million loan from the International Finance Corporation (IFC) to accelerate national expansion in Myanmar. Twenty new stores and improved standards are on the agenda for the next three years. Win Win Tint, Managing Director of City Mart Holding, commented: "IFC's investment is a sign of confidence in our business plan as well as in Myanmar's retail sector potential" (IGD, 2016d). One of the most popular chains is City Express, which opened the first convenience store in Yangon in 2011 and now operates around 40 stores. More than half of the City Express stores are open 24 hours a day and are located in the city center. In addition, the current figure of around $20 \mathrm{Grab} \&$ Go branches existing in 2015 is to be increased to 800 by 2020 (Myanmar Insider, 2015). The ABC Group, currently the largest convenience store operator in Myanmar, operates over 100 branches in Yangon and Mandalay. An expansion to 1000 stores is planned by 2020. The implementation is to take place via a franchising operation. The retailer is also keen to win new partners to expand new formats within its portfolio, including supermarkets and consumer markets (IGD 2015). The reporting on large investments in the area of online trading and mobile payments sounds promising (Retail in Asia, 2015b). It suggests that many retail formats should be simultaneously introduced to the market, similar to other developing countries that have recently opened up to the global world economy and experienced a rapid modernization of the retail landscape. As in China, and contrary to industrialized countries like Germany, trade formats do not develop over years, but rather skip development stages and are introduced more or less simultaneously (Hardaker, 2017: 61).

Foreign direct investment of US \$ 8.1 billion exceeded expectations in 2014-2015; and Myanmar's some 51 million people provide an enormous potential. Yangon has established itself as one of the top five Asian cities and is to be regarded as a global city by 2040 , while the rise in urbanization is contributing to a new lifestyle, which in turn raises an increasing demand for new products and shopping possibilities.

However, only a comparatively small number of retailers have entered the Myanmar retail market. The retail structure remains highly fragmented, market concentration is relatively low and the company density of modern trade formats greatly differs throughout the country.

\subsection{Regulative Dimension}

Within the regulatory dimension, institutional theory takes into account legal and political factors. With regard to Myanmar, state structural changes have had a significant impact on the attraction of foreign retailers in recent years. For a long time foreign retailers played no role at all.

Political events in 2012, including the return of democratic leader Aung San Suu Kyi to the Burmese Parliament, the release of political prisoners, the easing of media censorship, monetary reform and the introduction of a series of economic policy measures, triggered an avalanche of optimism on the part of potential investors in Myanmar and paved the way for increasing economic liberalization. The abolition of trade barriers by many countries has been a frequently undertaken by world leaders, including Barack Obama, who was the first US president to visit Myanmar in November 2012. The Constitution, which entered into force at the end of January 2011, stipulates that Myanmar pursues an economic system (Article 35). In a wider sense, this means that the regulatory dimension has an impact on a number of economic developments.

Myanmar's economy is predominantly agricultural, with $43 \%$ of its GDP attributatble to agricultural produce. The urbanization rate is relatively low compared to other Southeast Asian countries. About two-thirds of all employees live rurally (Federal Foreign Office, 2016). After decades as a clearly defined agricultural society, the last six years have shown significant progress in the development of an industrial base. The areas of textiles and clothing, food and beverages as well as building materials have grown strongly. Myanmar also has considerable natural gas reserves and other raw materials, as well as large agricultural areas and ample hydropower reserves (Federal Foreign Office, 2016). In 2014, the industrial sector accounted for $21 \%$ of GDP, doubling the almost $11 \%$ share it had in 2008. With the gradual opening-up and the introduction of laws and regulations, the improved legal environment has also helped foreigners to take advantage of Myanmar's market. Although legislation is not directly focused on the retail sector, it is clear that reforms pave the way for the development of modern retail trade. The same can be observed for other countries. A direct link between the most important reforms in the Chinese retail sector and the development and introduction of foreign retailers was described by Hardaker (2017). In Myanmar, restraint restrictions on market entry seem to have a strong positive impact on foreign retailers. Under the military regime foreign merchants were completely restricted from Myanmar for a sustained period. In 2014, the Myanmar Investment Commission lifted the restrictions. In order to attract foreign investment, its parliament passed amendments on foreign investment in November 2013. Germany Trade and Invest (2013) estimates that in the coming years the retail sector will "grow by around 6\% per year, at least in the rhythm of 
the gross domestic product." As a matter of fact, through the opening up of the market foreign food traders are increasingly given control over their activities.

Generally, there are several possibilities to enter the market. While licensing requires the least capital investment, this does not allow the parent company to acquire a strategic stake in the company. The option of a joint venture with a Myanmar competitor offers foreign retailers the opportunity to reduce their costs and the risk of entry by working with a partner who is familiar with the market. It is only by means of an acquisition (rapid entry into the market at high costs) or an independent market entry (establishing the retail chain from the ground up) that the company is fully entitled to ownership. In addition, the transaction costs play a significant role, as the time required to enforce a contract or register real estate is generally significantly higher than in the developed home markets (Khanna \& Palepu, 2010), thereby hindering the foundation of the company. Further influential factors include opening times and labor law. The longer-term goals of the Thai supermarket operator Siam macro also include expansion in Myanmar. However, the company announced that they would decide "once the political situation has become more clear" (IGD, 2016a). This includes, among other things, laws still in the legislative process or still in the design phase. Myanmar has had a Ministry of Environment only since 2011 and an environmental protection law since 2012 (Federal Foreign Office, 2016). Regarding the foreign investment law, the German Federal Foreign Office (2016: online) announced: "The law can be seen as a milestone towards a more open and legally more secure economic regulation for foreign investors, but it also leaves many questions regarding market access and investment protection unanswered. The regulatory framework and the licensing procedures for foreign investment continue to be very complex." In addition, accurate market evaluations are often difficult as there are hardly any reliable statistics available, and international organizations are freqeuently forced to make estimates (Federal Foreign Office, 2016).

Regarding the regulatory dimension within institutional theory, this article argues that a clear link between laws / regulations and the introduction of foreign retailers can be observed. This in turn means that there is a strong relationship between the point of entry, entry timing and entry mode with the strength of the rule of law in each country. In the case of Myanmar, the more stable government structures and the increased legal framework will have a positive effect on the decision-making process of retailers. However, companies are cautious in whether to invest in the market, as many laws are yet to be passed.

\subsection{Normative Dimension}

Myers and Alexander (2007) reveal that about two-thirds of the market penetration of Western retailers lie in their respective regions. As is apparent from previous investigations, markets perceived as culturally distant from the home market tend to be entered by an entry strategy that requires less financial commitments and less control. Evans et al. (2008) explain this verdict with the perception of major risks in culturally distant markets. This provides an explanation for the majority of Asian retailers, which are already established in the Myanmar market. In terms of retailing in Myanmar, the range of problematic dimensions is broad. From infrastructural to legal-political and organizational-technological barriers, the Myanmar market, in particular, is a difficult trading position which justifies a labeling of the market as difficult and uncertain. As mentioned before, modern Myanmar retailing is still in the development phase. $90 \%$ of retail sales are generated on traditional markets. The remaining $10 \%$, which are classified as 'modern', usually represent supermarkets, which focus on the three main population centers of Myanmar (Yangon, Naypyidaw and Mandalay). Accordingly, not only is the geographical reach of modern retail heavily restricted. Missing studies on consumer behavior and preferences in different cities also impede international retailers' entry. The understanding of and adaptation to the culture in Myanmar is another problem related to business activity. This adjustment seems particularly challenging in a country with pronounced ethnic-cultural heterogeneity and strong social-territorial and political disparities.

Culture, as defined by Hofstede (1997: 5), describes "the collective programming of the mind which distinguishes the members of one group or category of people from another." Hofstede (1997: 5, 10) also points out that culture influences the thinking, feeling and action pattern of a person, a country and a company. In the context of an examination of the cultural differences of more than 50 countries, Hofstede reveals four different dimensions: power gap, collectivism vs. individualism, femininity vs. masculinity and risk avoidance. Myanmar was not part of the original Hofstede studies, which is why Rarick and Nickerson (2006) state that there is no empirical data on the cultural classification of the country. Their results, however, show that Myanmar's culture is characterized by a low power gap, high femininity, moderate individualism and a high degree of uncertainty with a moderate long-term orientation. The cultural proximity to the Southeast Asian neighbors is thus given.

The socio-cultural framework conditions of a country are essential for the decision-making of a market entry, since they influence certain behavioral areas of the population and potential customers, organizations and institutions. These include, among others, the language of a country that ultimately represents the elementary 
means of communication between institutions and which must be adequately mastered. In the multi-ethnic country of Myanmar, a total of around a hundred different languages are spoken. The official Burmese language is spoken by about two-thirds of the population. Religion, a further socio-cultural framework, has a strong influence on customs in many countries. These influences are all the more pronounced, the stronger the institutions are connected with religious communities. Conflicts between religious communities can essentially determine what happens in particular countries. Myanmar has been strongly influenced by cultural and religious conflicts. In the North East, ethnic armed groups have been fighting the Tatmadaw for decades in their quest for self-administration within a federal system (Roewer, 2017). In the West, in the State of Rakhine, the Muslim Rohingya minority has been persecuted for decades. More than 1.1 million Rohingya Muslims are denied their citizenship in Myanmar and effectively denied a right to free movement and access to services such as education and healthcare (Roewer, 2017). Many areas are occupied by minorities and are regarded as unsafe and thus strongly hinder the arrival of international retailers. Values and attitudes, often directly shaped by religious influences, are essential to human behavior. Their importance for the behavior of buyers is obvious. These settings also include country-specific tastes and preferences, which must be taken into account in the retail sector. If they are highly heterogeneous in a country, the corresponding adjustment of the retailer to the demand on-the-spot is made more difficult. In regards to such adaptation, many Asian neighbors have an advantage and reduced barriers on account of cultural and linguistic proximity. In the context of the ASEAN agreements, Myanmar is closely linked to its neighbors, which in turn is due to the effect of regionalization, which decreases transaction costs. It is therefore not suprising that most of the foreign products are from East or South East Asia. Compared with other international suppliers, Asian retailers have a distinctive competitive advantage through regional cooperation, especially within the framework of the ASEAN Economic Community since 2016. The People's Republic of China, Hong Kong, Singapore, Malaysia and Thailand represent the traditional trading partners, while South Korea, Taiwan, Vietnam and Japan have been catching up significantly in recent years (Federal Foreign Office 2016).

Regarding the normative dimension within the framework of institutional theory, it is argued that retailers are more likely to expand into the Myanmar market if cultural and retail differences between the host country and the domestic market are small, or if the retailer's intention to adapt to the Myanmar market is correspondingly high. This can be confirmed not only by the majority of Asian retailers on-site, but also allows conclusions to be drawn on future market players. With regard to Myanmar, the country's strong cultural and religious heterogeneity and the conflicts that have been associated with it for many years represent a significant obstacle to market entry.

\subsection{Cognitive Dimension}

From a cognitive perspective, cultural legitimacy derives from the assumption of a common way of thinking. Huang and Sternquist (2007: 622) point out that "the imprinting influence of the entry mode used in by a retailer in its earlier entries will result in the same entry mode in later entries especially when the situations are similar to the past." Companies are learning not only from their own experiences, but also tend to learn from the experience of others, which often leads to the imitation of competitors. Later expanding companies take advantage of the fact that the entry risk and the associated costs are already covered by so-called first-movers (Lieberman \& Montgomery, 1988). Huang and Sternquist (2007: 623) argue that retailers avoid or postpone entry decisions regarding a "totally unknown foreign area". In addition, they argue that companies with no previous experience can be guided by the behavior of other retailers. Many factors, such as comparatively low monthly household income, may pose a greater obstacle for international retailers than for Asian firms. Moreover, regional and ethnic conflicts discourage foreign firms especially in view of the unpredictability of circumstances. The differences between the already entered markets, which are usually characterized by clear structures and higher available consumer spendings, are correspondingly large. This is confirmed by the high number of companies already mentioned in the Asian region, which positioned themselves at an early stage in Myanmar and are already operating in similar markets. With the first-movers who have already entered Myanmar, the first retailers are currently establishing themselves. In particular, retailers pursuing an international expansion strategy and already established in Asia will be among the first retailers to enter Myanmar. This is illustrated, for example, by the Singapore-based Parkson department store chain, which operates inter alia in Malaysia, Vietnam and Indonesia. Parkson entered the Myanmar market in 2012 and promises growth in sales of $20-30 \%$ in the first five years (Retail in Asia, 2012). One of the largest mobile telephones and electronic product sales chains in Vietnam, Mobile World, also plans to open stores in Myanmar. In future, the company will distribute three product groups: mobile phones, electronics and food (IGD, 2016b). According to media reports (Retail in Asia, 2016), the Japanese trade giant AEON will be the first foreign supermarket group to open its stores. As part of a 
joint venture with the local Creation Group, AEON will provide the majority of US \$ 8.1 million funding. At first, 14 supermarkets belonging to the Orange chain, which are mainly operated in Yangon, are taken over before additional stores will be opened. The stores will sell AEON's own brands, most of which are produced in Thailand (Retail in Asia, 2016; IGD, 2016c). These examples illustrate the fact that mainly Asian retailers are entering the market as they are already familiar with similar markets and derive cultural legitimacy through the adoption of a common way of thinking.

With each successful expansion, the likelihood that other companies will follow increases. Consequently, if retailers are able to make use of earlier comparable successes in their own or the expansion strategy of their competitors, the company is more willing to expand. As far as Myanmar is concerned, Asian retailers in particular are entering the market and will do so in the future. As far as non-Asian retailers are concerned, it is likely that internationally experienced retailers, who thus have a greater experience with market entry in economically and infrastructurally weaker countries, will sooner enter the Myanmar market.

\section{Conclusion}

Companies prefer to enter markets with high attractiveness and low market risk. Despite the growing attractiveness of the retail market in Myanmar (rising GDP, rising household income, etc.), many retailers are hesitant to expand to Myanmar. This article presents institutional theory as a complementary framework for explaining the selection criteria of the international retailers of foreign market penetration in Myanmar. Within the framework of institutional theory, this work emphasizes the particular perspective of grocery retailers, who generally have to adapt to the respective market even more strongly than other industries, since they are forced to respond to different consumer preferences like no other sector. The barriers to the Myanmar retail market still appear relatively high. Three points, which are by no means exclusive, are to be emphasized at this point. Firstly, the retail market in Myanmar is a consumer market with unique characteristics: not only on the basis of its own economic policy history, but also on its consumers, whose income is largely not enough to be a decisive factor in the decision-making process of foreign companies. Moreover, the food retailer strongly has to adapt to local conditions, e.g. different tastes and regulations, which in turn result in higher costs. Secondly, as food businesses tend to procure the vast majority of their products from the respective market, they are automatically intertwined with the local supply and logistics infrastructure and have to deal with the respective problems. Therefore, the inconsistencies of the local suppliers are a great risk in terms of quality. Thirdly, the immense capital investments in form of branches, distribution and logistics infrastructures make retailers sensitive and vulnerable to real estate markets and regulatory systems, as Tacconelli and Wrigley (2009: 54) pointed out earlier. With still very new and partly missing regulations in the real estate sector, Myanmar shows further uncertainties in this regard. Since the modern retail sector so far has concentrated mainly on three cities, the expansion also reveals geographic boundaries.

The present work has described the arrival of the first international retailers to Myanmar. As a result, it must be discussed whether they are capable of implementing so-called first-mover benefits. It seems that, as part of the cognitive dimension, overseas retailer decisions are neglected; rather the lacking link to similar previous successful market entries stand in the foreground. Moreover, the regulatory framework, which still leaves a number of questions unanswered, seems too uncertain. This provides an argument for the absence of many international retailers, especially from Europe. These results are consistent with previous studies by Evans and Bridson (2005), Evans et al. (2008) and Yu and Ramanathan (2012: 230), which reveal that the retail internationalization strategy is strongly influenced by the conditions of the foreign market. Consequently, retailers with a multinational orientation, as described by Zentes et al. (2011: 155) tend to enter the Myanmar market as they are focused on the adjustment of heterogeneous markets. Likewise, companies using Sternquist's multinational expansion model (1997: 263) tend to deal with changing retail concepts in order to adapt to the cultural differences of the respective country, thereby exploiting a locational advantage. The example of Myanmar shows that mainly Asian retailers have entered the market so far and that the obstacles presented still hinder or delay a market entry on the part of many Western retailers. As pointed out correctly by Huang and Sternquist (2007: 626), the dimensions of institutional theory exert influence on different corporate decisions and levels. While the regulatory dimension is oriented to the country level, corporate or cultural levels are influenced by normative and cognitive dimensions. However, as described in this paper, the three dimensions seem to influence one another. Consequently, retailers must take into account all institutional forces. Although institutional theory is a good starting point for an analysis framework of macroeconomic factors, it is far from being a precise and clear framework. There is an almost unlimited number of variables that emerge from each dimension. Since it does not contradict the economic perspective, this paper proposes institutional theory as complementary and not as a substitute for existing theories such as Dunning's eclectic theory or transaction cost analysis. 
However, anyone who wants to benefit from the opening and growing retail market in Myanmar must strategically overcome geographical, cultural, and economic diversity and uncertainty. Future research should further explore how institutional theory and other prevailing theories can be integrated to enhance their explanatory dimension to international trading.

Myanmar is becoming increasingly attractive to retailers from all over the world. Howard Schultz, CEO of coffee giant Starbuck, said in 2013 that the company wants to enter Myanmar "[W] ithin the next couple of years" (The Jakarta Post, 2013), after successful market penetration in India and Vietnam. The World Economic Forum Summit in East Asia 2013 took place in Naypyidaw and illustrates the growing interest in a country whose economy is in the midst of the world's fastest growing economic region and yet still underdeveloped. Although it is easy to anticipate rapid economic growth and an accompanying rising standard of living, there is a risk that the dynamics will be positively assessed by the above-mentioned problems. Seekins (2015: 115) argues, for example, that the political transition that has taken place in Myanmar since 2011 has often been misunderstood by foreign politicians and economists, "in part due to wishful thinking and in part to perhaps willful ambiguity on the part of President UThein Sein and the other retired military officers who still rule the country."

However, before some of the above-mentioned problems can be solved completely, the risks associated with a market entry will represent an obstacle for many retailers. This paper confirms the question of the extent to which modernization and internationalization have a positive or negative impact on retailing in Myanmar and its institutions. It is important to discuss the further obstacles and the entry of modern and international retailers continuously and above all critically. The Asian retailers, which are currently expanding strongly in Myanmar, are setting the course for successful first-mover strategies and possible imitators.

\section{References}

Akehurst, G., \& Alexander, N. (1995). Developing a Framework for the Study of the Internationalisation of Retailing. The Service Industries Journal, 15(4), 203-209. https://doi.org/10.1080/02642069500000058

Akther, S., \& Equbal, I. (2012). Organized Retailing in India - Challenges and Opportunities. International Journal of Multidisciplinary Research, 2(1), 281-291.

Aldrich, H. E., \& Fiol, C. M. (1994). Fools rush in? The institutional context of industry creation. Academy of Management Review, 19, 645-670.

Alexander, N. (1997). International Retailing. London, UK: Wiley Business and Economics.

Alexander, N., \& De Lira e Silva, M. (2002). Emerging Markets and the Internationalisation of Retailing: The Brazilian Experience. International Journal of Retail \& Distribution Management, 2(1), 300-314.

Alexander, N., \& Quinn, B. (2002). International Retail Divestment. International Journal of Retail and Distribution Management, 30(1), 122-123. https://doi.org/10.1108/09590550210418137

Alexander, N., Quinn, B., \& Cairns, P. (2005). International Retail Divestment Activity. International Journal of Retail and Distribution Management, 33(1), 112-125. https://doi.org/10.1108/09590550210418137

Amine, A., \& Tanfous, F. H. B. (2012). Exploring Consumers' Opposition Motives to the Modern Retailing Format in the Tunisian Market" International Journal of Retail \& Distribution Management, 40(7), 510-527. https://doi.org/10.1108/09590551211239837

Appel, A. (2014). Zwischen Basar und Supermarkt: Strukturelle Veränderungen im Lebensmitteleinzelhandel der Türkei unter Berücksichtigung von Globalisierungsprozessen. Marburg: Philipps-Universität Marburg.

Aten, K., \& Howard-Grenville, J. (2012). Encouraging trade at the boundary of organizational culture and institutional theory. Journal of Management Inquiry, 21(1), 114-117. https://doi.org/10.1177/1056492611419803

A. T. Kearney (2016). The 2016 Global Retail Development Index - Global Retail Expansion at a Crossroads. Düsseldorf: A.T. Kearney Group, Juni 2016.

Atsmon, Y., Child, P., Dobbs, R., \& Narasimhan, L. (2012). Winning the \$30 Trillion Decathlon: Going for Gold in Emerging Markets. McKinsey Quarterly: August Ausgabe.

Au-Yeung, A. Y. S. (2003). International Transfer of Retail Know - How Through Foreign Direct Investment from Europe to China. J. Dawson; M. Mukoyama; S. C. Choi; R. Larke (Hrsg.) The Internationalisation of Retailing in Asia. London, UK: RoutledgeCurzon, 136-154.

https://doi.org/10.4324/9780203180495_chapter_8

Burt, S. (1991). Trends in the Internationalization of Grocery Retailing: The European Experience. The 
International Review of Retail, Distribution and Consumer Research, 1(4), 487-515.

Burt, S., Dawson, J., \& Sparks, L. (2004). The International Divestment Activities of European Grocery Retailers. European Management Journal, 5, 483-492.

Cao, L., \& Pederzoli, D. (2013). International Retailers Strategic Responces to Institutional Environment of Emerging Market - Multiple Case Studies in China. International Journal of Retail and Distribution Management, 41(4), 289-310. https://doi.org/10.1108/09590551311330555

Cavusgil, S. T., Chauri, P. N., \& Akcal, A. A. (2013): Doing Business in Emerging Markets. $2^{\text {nd }}$ edition. U.K.: London: Sage Publications Ltd.

Christopherson, S. (2007). Barriers to 'US style' Lean Retailing: The Case of Wal-Mart's Failure in Germany. Journal of Economic Geography, 7(4), 451-469. https://doi.org/10.1093/jeg/lbm010

Codron, J. M., Bouhsina, Z., Fort, F., \& Coudel, E. (2004). Supermarkets in Low Income Mediterranean Countries: Impacts on Horticultural Systems. Development Policy Review, 22(5), 587-602. https://doi.org/10.1111/j.1467-7679.2004.00266.x

Coe, N. M. (2004). The Internationalisation / Globalisation of Retailing: Towards an Economic-Geographical Research Agenda. Environment and Planning, 36(9), 1571-1594. https://doi.org/10.1068/a36241

Coe, N., \& Lee, J. (2006). The Strategic Localization of Transnational Retailers - The Case of Samsung-Tesco in South Korea. Economic Geography, 82(1), 61-88. https://doi.org/10.1111/j.1944-8287.2006.tb00288.x

Coe, N., \& Wrigley, N. (2007). Host Economy Impacts of Transnational Retail: The Research Agenda. Journal of Economic Geography, 7(4), 341-371. https://doi.org/10.1093/jeg/lbm012

Corstjens, M., \& Lal, R. (2012). Retail Doesn't Cross Borders. Here's Why and What to Do About it. Harvard Business Review, April: 104-111.

Dacin, M. T. (1997). Isomorphism in context: The power and prescription of institutional norms. Academy of Management Journal, 40(1), 46-81.

Davis, P., Desai, A., \& Francis, J. (2000). Mode of International Entry: An Isomorphism Perspective. Journal of International Business Studies, 31(2), 239-258.

Dawson, J., \& Mukoyama, M. (2014a). Future Directions of Retailer Internationalization. J. Dawson; M. Mukoyama (Hrsg.) Global Strategies in Retailing - Asian and European Experiences. New York, USA: Routledge: 227-238.

Dawson, J., \& Mukoyama, M. (2014b). Recent Developments in Retail Internationalization. J. Dawson; M. Mukoyama (Hrsg.) Global Strategies in Retailing - Asian and European Experiences. New York, USA: Routledge, 5-36.

D'Haese, M., \& Van Huylenbroeck, G. (2005). The Rise of Supermarkets and Changing Expenditure Patterns of Poor Rural Households - Case Study in the Transkei Area, South Africa. Food Policy, 30(1), 97-113. https://doi.org/10.1016/j.foodpol.2005.01.001

DiMaggio, P. J., \& Powell, W. (1983). 'The iron cage revisited' institutional isomorphism and collective rationality in organizational fields. American Sociological Review, 48, 147-160.

Dunning, J. H. (1977). The International Allocation of Economic Activity. Trade, Location of Economic Activity and the MNE: A Search for an Eclectic Approach, 395-418.

Dunning, J. H. (2003). Some antecedents of internalization theory. Journal of International Business Studies, 34(2), 108-115. https://doi.org/10.1057/palgrave.jibs.8400010

Euromonitor (2014). Markets of the Future in Myanmar [Online] Juni 2014. http://www.euromonitor.com/markets-of-the-future-in-myanmar/report

Euromonitor. (2013). The Internationalization of Retailing - Sucess, Failure and the Importance of Adapting to the Market [Online] http://web.euromonitor.com/Portals/71592/docs/FINAL_The_ Internationalisation_of_Retail_DigitalVersion.pdf

Evans, J., \& Bridson, K. (2005). Explaining Retail Offer Adaptation through Psychic Distance. International Journal of Retail \& Distribution Management, 33(1), 69-78. https://doi.org/10.1108/09590550510577138

Evans, J., Bridson, K., Byrom, J., \& Medway, D. (2008). Revisiting Retail Internationalisation - Drivers, Impediments and Business Strategy. International Journal of Retail \& Distribution Management, 36(4), 
260-280. https://doi.org/10.1108/09590550810862679

Faiguenbaum, S., Berdegué, J. A., \& Reardon, T. (2002). The Rise of Supermarkets in Chile: Effects on Producers in the Horticulture, Dairy, and Beef Chains. Development Policy Review, 20(4), 459-471. https://doi.org/10.1111/1467-7679.00183

Federal Foreign Office. (2016). Wirtschaftspolitik Myanmar. [Online] http://www.auswaertiges-amt.de/DE/Aussenpolitik/Laender/Laenderinfos/Myanmar/Wirtschaft_node.html

Fliguié , M., \& Moustier, P. (2009). Market Appeal in an Emerging Economy: Supermarkets and Poor Consumers in Vietnam. Food Policy, 34(2), 210-217.

Germany Trade and Invest. (2013). Vertrieb und Handelsvertretersuche - Myanmar, Bonn: Germany Trade and Invest.

Gielens, K., \& Dekimpe, M. G. (2002). European Grocery Retailers Caught by Internationalisation Fever. European Retail Digest, 35(1), 1.

Hagen, J. M. (2002). Causes and Consequences of Food Retailing Innovation in Developing Countries: Supermarkets in Vietnam. Cornell University, New York, USA.: Working Paper, Department of Applied Economics and Management.

Halpete, J., Iyer, K. V. S., \& Park, S. C. (2008). Walmart in India: A Success or Failure? International Journal of Retail \& Distribution Management, 36(9), 701-713. https://doi.org/10.1108/09590550810890948

Handelsblatt. (2010). Aldi verlässt Griechenland [Online] 16th July 2010 http://www.handelsblatt.com/unternehmen/handel-dienstleister/rueckzugaldi-verlaesst-griechenland/349224 2.html

Hardaker, S. (2017). The changing role of international grocery retailers in China, 1978-2016. History of Retailing and Consumption, 3(1), 53-69. https://doi.org/10.1080/2373518X.2017.1279870

Hassan, H., Sade, A. B., \& Rahman, M. S. (2013). Malaysian Hypermarket Retailing Development and Expansion. International Journal of Retail \& Distribution Management, 41(8), 584-595. https://doi.org/10.1108/IJRDM-09-2012-0085

Hofstede, G. (1980). Culture's Consequences. Thousand Oaks, Canada: Sage.

Hofstede, G. (1997). Cultures and Organizations: Software of the Mind. USA: McGraw - Hill.

Huang, Y., \& Sternquist, B. (2007). Retailers' Foreign Market Entry Decisions: An Institutional Perspective. International Business Review, 16(5), 613-629. https://doi.org/10.1016/j.ibusrev.2007.06.005

IGD. (2014). Leading Retailers Review: Carrefour, Walmart, Tesco, Metro [Online] 9. Juli 2014. http://retailanalysis.igd.com/Hub.aspx?id=23\&tid=3\&nid=12747\&ecid=10686\&uid=296571

IGD. (2015). ABC in Myanmar looking to expand [Online] 22. September 2015. http://retailanalysis.igd.com/Hub.aspx?id=19\&tid=2\&cid=135\&nid=14354

IGD. (2016a). Siam Makro to expand across Asia [Online] 21. April 2016. http://retailanalysis.igd.com/Hub.aspx?id=19\&tid=2\&cid=135\&nid=15194

IGD. (2016b). Asia online retail roundup [Online] http://retailanalysis.igd.com/Hub.aspx $2 i d=19 \&$ tid=2\&cid=135\&nid=14822

IGD. (2016c). Aeon to enter Myanmar [Online] 26. Januar 2016. http://retailanalysis.igd.com/Hub.aspx $?$ id=19\&tid=2\&cid=135\&nid=15584

IGD. (2016d). City Mart to expand in Myanmar. [Online] 13. Januar 2016. http://retailanalysis.igd.com/Hub.aspx?id=19\&tid=2\&cid=135\&nid=14765

Khanna, T., \& Palepu, K. G. (2010). Winning in Emerging Markets: A Road Map for Strategy and Execution. Massachusetts, USA: Harvard Business Publishing.

King, G., Keohane, R. O., \& Verba, S. (1994). Designing Social Inquiry: Scientific Inference in Qualitative Research. Princeton: Princeton University Press.

Kogut, B., \& Singh, H. (1988). The Effect of National Culture on the Choice of Entry Mode. Journal of International Business Studies, 19(3), 411-432. https://doi.org/10.1057/palgrave.jibs.8490394

Larke, R. (2006). Trends in Retailing in East Asia,, M. Krafft; M. K. Mantrala (Hrsg.) Retailing in the $21^{\text {st }}$ Century - Current and Future Trends. Heidelberg: Spinger Verlag, 77-93. 
https://doi.org/10.1007/3-540-28433-8_6

Lawrence, T. B., Winn, M. I., \& Jennings, P. D. (2001). The temporal dynamics of institutionalization. Academy of Management Review, 26(4), 624-644.

Liebermann, M. B., \& Montgomery, D. B. (1988). First-Mover Advantages. Strategic Management Journal 9 (Special Issue: Strategy Content Research): 41-58.

Lorentz, H., \& Hilmola, O. P. (2008). Supply Chain Management in Emerging Market Economies: A Re view of the Literature and Analysis of the Russian Grocery Retail Sector. International Journal of Integrated Supply Management, 4(2), 201-229. https://doi.org/10.1504/IJISM.2008.016618

Lounsbury, M., \& Beckman, C. (2015). Celebrating organization theory. Journal of Management Studies, 52, 288-308. https://doi.org/10.1111/joms.12091

Maruyama, M., \& Trung, L. V. (2007). Supermarkets in Vietnam: Opportunities and Obstacles. Asian Economic Journal, 21 (1), 19-46. https://doi.org/10.1111/j.1467-8381.2007.00245.x

McKinsey. (2013). Myanmar's moment: Unique opportunities, major challenges. Juni 2013: McKinsey Global Institute. https://www.mckinsey.com/global-themes/asia-pacific/myanmars-moment

Meyer, J. W., \& Rowan, B. (1977). Institutionalized Organizations: Formal Structure as Myth and Ceremony. American Journal of Sociology, 83(2), 340-363. https://doi.org/10.1086/226550

Myanmar Insider. (2015). Yangon retail market ripe for expansion [Online] Januar 2015. http://www.myanmarinsider.com/yangon-retail-market-ripe-for-expansion/

Myers, H., \& Alexander, N. (2007). The Role of Retail Internationlisation in the Establishment of a European Retail Structure. International Journal of Retail \& Distribution Management, 35(1), 6-19. https://doi.org/10.1108/09590550710722314

Nguyen, H., Wood, S., \& Wrigley, N. (2013). The Emerging Food Retail Structure of Vientam: Phase of Expanion in a Post-Socialist Environment. International Journal of Retail \& Distribution Management, 48(8), 596-626. https://doi.org/10.1108/IJRDM-07-2012-0069

Oxford Business Group. (2016). The Report: Myanmar 2016 [Online] http://www.oxfordbusinessgroup.com/myanmar-2016/industry-retail

Palmer, M. (2004). International Retail Restructuring and Divestment: The Experience of Tesco. Journal of Marketing Management, 20(9/10), 1075-1105. https://doi.org/10.1362/0267257042405213

Peng, M. W., \& Heath, P. S. (1996). The growth of the firm in planned economies in transition: Institutions, organizations, and strategic choice. Academy of Management Review, 21(2), 492-528.

Planet Retail. (2016): BURGER KING makes tentative entry to Myanmar [Online] 12. August 2016. https://www.planetretail.net/NewsAndInsight/article/155083?utm_source=email\&utm_medium=email\&ut m_campaign=GlobalRetailNewsInsight\&senddate $=12002016$

Powell, W., \& DiMaggio, P. (1991). The New Institutionalism in Organizational Analysis. Chicago, IL: University of Chicago Press.

Rarick, C. A., \& Nickerson, I. (2006). An Exploratory Study of Myanmar Culture Using Hofstede's Value Dimensions (20. Februar 2006). https://doi.org/10.2139/ssrn.1114625

Reardon, T., \& Gulati, A. (2008). The Rise of Supermarkets and Their Development Implications: International Experience Relevant for India. Washington, USA: International Food Policy Research Institute

Reardon, T., Berdegué, J. A., Medina, R., \& Aguirre, M. (2007b). The Rise of Supermarkets in Mexico: Implications for the Domestic Horticultural Supply Chain and Development. East Lansing: Michigan State University: Report to USDA.

Reardon, T., Henson, S., \& Berdegué, S. (2007a). Proactive Fast-Tracking' Diffusion of Supermarkets in Developing Countries: Implications for Market Institutions and Trade. Journal of Economic Geography, 7(4), 399-431. https://doi.org/10.1093/jeg/lbm007

Reinartz, W., Dellaert, B., Krafft, M., \& Kumar V. (2011). Retailing Innovations in a Globalizing Retail Market Environment. Journal of Retailing, 87(1), 53-66. https://doi.org/10.1016/j.jretai.2011.04.009

Retail in Asia. (2012): Department store Parkson taps Vietnam experience for Myanmar push [Online] 19. September 
http://www.retailinasia.com/in-shops/department_stores/department-store-parkson-taps-vietnam-experience -myanmar-p/

Retail in Asia. (2014). Gap to be $1^{\text {st }}$ US retailer to enter Myanmarmarket [Online] 10. Juni 2014. http://www.retailinasia.com/in-trends/news/manufacturing_logistics/gap-be-1st-us-retailer-enter-myanmar -market/

Retail in Asia. (2015a). Krispy Kreme to Open 10 Shops in Myanmar [Online] 27. August 2015. http://www.retailinasia.com/in-sectors/food_beverage/krispy-kreme-open-10-shops-myanmar/

Retail in Asia. (2015b). Taking Stock: Myanmar fast gearing up for m-commerce, m-payment [Online] 23. Februar

2015. http://www.retailinasia.com/in-trends/news/business_finance/taking-stock-myanmar-fast-gearing-m-comm erce-m-payment/

Retail in Asia. (2016). This company is Myanmar's first foreign retailer. [Online] August 2016. http://www.retailinasia.com/in-markets/rest-of-asia/in-asia-pacific/this-company-is-myanmars-first-foreignretailer/

Roewer, R. (2017). Myanmar's National League for Democracy at a Crossroads, GIGA Focus Asia, [Online] 01. April 2017 https://www.giga-hamburg.de/en/publication/myanmars-national-league-for-democracy-at-a-crossroads

Sakarya, S.. Eckman, S., \& Hyllegard, K. H. (2007). Market Selection for International Expansion - Assessing Opportunities in Emerging Markets. International Marketing Review, 24(5), 208-238. https://doi.org/10.1108/02651330710741820

Salmon, W., \& Tordjman, A. (1989). The Internationalisation of Retailing. International Journal of Retailing, 4(2), 3-16. https://doi.org/10.1108/EUM0000000002916

Scott, W. R. (1995): Institutions and Organizations. Thousand Oaks, CA, SAGE.

Seekins, D. M. (2015). Japan's Development Ambitions for Myanmar: The Problem of 'Economics before Politics'. Journal of Current Southeast Asian Affairs, 113-138.

Senauer, B., \& Reardon, T. (2011). The Global Spread of Modern Food Retailing. G. Hamilton; M. Petrovic; B. Senauer (Hrsg.) The Market Makers - How Retailers are Reshaping the Global Economy. U.K.: Oxford: University Press, 271-290. https://doi.org/10.1093/acprof:oso/9780199590179.003.0011

Senge, K. (2004). Der Fall Wal-Mart: Institutionelle Grenzen ökonomischer Globalisierung. Working Paper, 4, July: Dortmund University.

Sherer, P. D., \& Lee, K. (2002). Institutional change in large law firms: A resource dependency and institutional perspective. Academy of Management Journal, 45(1), 102-119. https://doi.org/10.2307/3069287

Simon, H. A. (1959). Theories of Decision-Making in Economics and Behavioral Science. The American Economic Review, 49(3), 253-283.

Sternquist, B. (1997). International Expansion of US Retailers. International Journal of Retail \& Distribution Management, 25(8), 262-268. https://doi.org/10.1108/09590559710178347

Suchman, M. C. (1995). Managing legitimacy: Strategic and institutional approaches. Academy of Management Review, 20(3), 571-610.

Swoboda, B., Pennemann, K., \& Taube, M. (2012). The Effects of Perceived Brand Globalness and Perceived Brand Localness in China: Empirical Evidence on Western, Asian, and Domestic Retailers. Journal of International Marketing, 20(4), 72-95. https://doi.org/10.1509/jim.12.0105

Tacconelli, W., \& Wrigley, N. (2009). Organizational Challenges and Strategic Responses of Retail TNCs in Post - WTO - Entry China. Economic Geography, 85(1), 49-73. https://doi.org/10.1111/j.1944-8287.2008.01003.x

Tandon, S., Landes, M., \& Wooverton, A. (2011). Analyzing Modern Food Retailing Expansion Drivers in Developing Countries. Agribusiness, 27(3), 327-343. https://doi.org/10.1002/agr.20267

The China Post. (2012). Coca-Cola back in Myanmar officially after 60 years [Online] 12. September 2012. http://www.chinapost.com.tw/business/global-markets/2012/09/12/354080/Coca-Cola-back.htm

The Jakarta Post. (2013). Starbucks sees Myanmar entry in couple of years. [Online] 13. Mai 2013 http://www.thejakartapost.com/news/2013/05/13/starbucks-sees-myanmar-entry-couple-years.html 
The Jakarta Post. (2015). Myanmar KFC fans queue for hours for first taste of US fast food [Online] 30. Juni 2015.

http://www.thejakartapost.com/news/2015/06/30/myanmar-kfc-fans-queue-hours-first-taste-us-fast-food.ht $\mathrm{ml}$

The Wall Street Journal. (2013). Coke and Unilever Invest \$1 Billion in Myanmar [Online] 5. Juni 2013. http://www.wsj.com/articles/SB10001424127887324423904578525140634650424

Traill, W. B. (2006). The Rapid Rise of Supermarkets? Development Policy Review, 24(2), 163-174. https://doi.org/10.1111/j.1467-7679.2006.00320.x

Turban, M., \& Wolf, J. (2008). Absatzbezogene Strategien der Internationalisierung des Lebensmittel-Discountmarkts bei Aldi und Lidl im Vergleich. Düsseldorf Working Papers in Applied Management and Economics, 3.

Vida, I., Reardon, J., \& Fairhurst, A. (2000). Determinants of International Retail Involvement: The Case of Large U.S. Retail Chains. Journal of International Marketing, 8(4), 37-60. https://doi.org/10.1509/jimk.8.4.37.19792

Wang, S., \& Zhang, Y. (2005). The New Retail Economy of Shanghai. Growth and Change, 36(1), 41-73. https://doi.org/10.1111/j.1468-2257.2005.00266.x

Williamson, S. (1979). Transaction-Cost Economics: The Governance of Contractual Relations. The Journal of Law and Economics, 22(2), 233-261. https://doi.org/10.1086/466942

Williamson, S. (1981). The Economics of Organization: The Transaction Cost Approach. American Journal of Sociology, 87(3), 548-577. https://doi.org/10.1086/227496

Xu-Priour, D., \& Cliquet, G. (2013). In-Store Shopping Experience in China and France - The Impact of Habituation in an Emerging Country. International Journal of Retail \& Distribution Management, 41(9), 706-732. https://doi.org/10.1108/IJRDM-05-2013-0108

Young, S. C. (2011). The Knowledge Transfer of Tesco UK into Korea, in Terms of Retailer Brand Development and Handling Processes. Journal of Distribution Science, 9(2), 13-24. https://doi.org/10.15722/jds.9.2.201106.13

Yu, W., \& Ramanathan, R. (2012). Effects of Business Environment on International Retail Operations - Case Study Evidence from China. International Journal of Retail \& Distribution Management, 40(3), 218-234. https://doi.org/10.1108/09590551211207175

Zentes, J., Morschett, D., \& Schramm-Klein, H. (2011). Strategic Retail Management - Text and International Cases. 2.Auflage. Wiesbaden, Germany: Gabler.

Zhen, Y. (2007). Globalization and the Chinese Retailing Revolution - Competing in the World's Largest Emerging Market. Oxford, UK: Chandos Publishing. https://doi.org/10.1533/9781780632292

Zilber, T. B. (2012). The relevance of institutional theory for the study of organizational culture. Journal of Management Inquiry, 21(1), 88-93. https://doi.org/10.1177/1056492611419792

\section{Copyrights}

Copyright for this article is retained by the author(s), with first publication rights granted to the journal.

This is an open-access article distributed under the terms and conditions of the Creative Commons Attribution license (http://creativecommons.org/licenses/by/4.0/). 